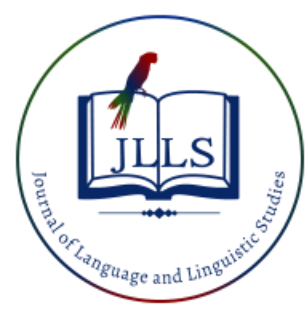

Available online at www.jlls.org

JOURNAL OF LANGUAGE

AND LINGUISTIC STUDIES

ISSN: $1305-578 \mathrm{X}$

Journal of Language and Linguistic Studies, 17(3), 1141-1156; 2021

\title{
"Myscene Tube"- A web channel to enhance English speaking skills in an ESL classroom
}

\author{
Chee Kooi Lian a iD, Devanageswari Kathiyaiah b ${ }^{\text {iD }}$, Farah Hani ${ }^{\text {c }}$ iD, \\ Vinotheni Chanderan d1 (iD), Melor Md Yunus e (iD \\ APA Citation: \\ a,b,c,d,e Universiti Kebangsaan Malaysia, Bangi, Selangor, Malaysia.
}

Kooi Lian, C., Kathiyaiah, D., Hani, F., Chanderan, V., \& Yunus, M. M. (2021). "Myscene Tube”- A web channel to enhance English speaking skills in an ESL classroom. Journal of Language and Linguistic Studies, 17(3), 1141-1156. Doi: 10.52462/j1ls.81

Submission Date:01/04/2021

Acceptance Date:20/07/2021

\begin{abstract}
Education has undergone unregulated changes in terms of learning and teaching in this Industrial Revolution 4.0. Along with this, technological advancement has unlocked multiple ways for educators and learners to apply online resources in their teaching and learning process. It is vital to get more attention in the expansion of learners' skills, especially in speaking. However, learners appeared to be lacking in speaking skills and as well as lacking the confidence to utilize the target language (English). The use of traditional teaching approaches also contributes to the reason why learners feel bored and perform badly in speaking. In order to tackle these problems, using "MyScene Tube" is a promising solution to expand learners' confidence and English-speaking skills. Therefore, this paper aims to investigate learners' confidence in utilizing the English language through the implementation of the "MyScene Tube" web channel. In this mixed-method research, survey questionnaires and YouTube Analysis were used to collect data from 118 Senior 2 learners of a secondary school in Klang, Selangor. Then, the questionnaire was analyzed using descriptive analysis. In brief, the research finding shows that "MyScene Tube" could assist learners to perform better in speaking activities. It is recommended that this study could be used by future researchers to explore the effectiveness of this innovation in enhancing learners' ability in different skills of the English Language.
\end{abstract}

Keywords: 21st-century learning; language classrooms; speaking skills; web channel; MyScene Tube

\section{Introduction}

In this new century, the learners' academic style is distinct from the prior generation, because they become more realistic and personally interested in the learning process as stated by Kozinski (2017). Learners of the 21 st century are the ones fully involved in their learning process. They welcome challenges and enjoy a highly interactive learning environment and group discussion. It is extremely crucial for the educators to come up with lesson planning which could cater to the preferences of the current generation learners to keep them engaged throughout the lesson along with Industrial Revolution 4.0. Consequently, many educators are frustrated by the array of accessible language classroom

\footnotetext{
${ }^{1}$ Corresponding author.

E-mail address: P106445@siswa.ukm.edu.my
} 
methodologies and techniques. Throughout the quest for the right approach, they ought to closely analyze the learners' ability to better understand the skills required to learn information. Based on that, the responsibilities of educators will continually change to address the demands of today's learners.

Besides the conventional position of the instructor as supervisor, certain more appropriate positions, such as associate or facilitator, are pursued that are more applicable to this current century age, which aims to enhance the transformation of the curriculum. As a consequence, educators have started to look at the priorities, features and results of the implementation of the technology approach in English language classrooms that can boost learners' confidence and speaking ability in utilizing the language. The twenty-first-century capabilities criteria tend to advocate for technology-based strategies to learning without specifically stating so. This is what makes the current volume so timely as to bridge these new standards of learning with enabling pedagogy and technology (Zeidler, 2016).

English is known as the International language and is widely used all over the world. (Pazilah et al, 2019) stated that, to a few individuals, English acts as their first language (EFL) and it has gotten to be the dialect for instruction and educational modules in numerous nations. Besides that, English has been used as the Second Language in countries like Malaysia, Singapore, India, Netherlands, etc (Pazilah et al, 2019). According to Lukas \& Yunus (2021), learning English as a Second Language (ESL) had continuously never been simple particularly for the remedial learners who continuously required educators to screen and mentor them throughout the class. In addition, in Malaysia, ESL learners also found it difficult to master the language amid the COVID-19 time (Yen \& Mohamad, 2020). Moreover, (Yunus et al, 2021) said that in Malaysia, the English Language is contemplated as a second language and can be seen as a foreign language by residents who have bounded exposure to English. The procurement of the English dialect is significantly emphasized in the Malaysian instruction framework, whereby it is instructed as an obligatory subject in primary, secondary, and tertiary instruction. In spite of the fact that the English language is emphatically highlighted within the instruction framework, Malaysians are still distant from accomplishing the yearnings of the nation to have a nation that's capable within the English language (Hayriye, 2008). The declining standard of the English language in Malaysia isn't because it was a major concern inside the instruction system but to boot vital in gathering the demands of globalization in instruction.

In an English class in the past, the educator had to spend most of the time in the classroom teaching, while students would always passively gain linguistic information either from the teacher or from the textbook, but their ability to communicate could not be properly taught and developed (Precintha Rubini et al, 2019). In the current time, speaking is a challenging skill where it plays the most crucial role among the four essential skills in language learning. On the side of composing, it could be an exceptionally critical proficiency that empowers learners to communicate with others successfully. In a speaking class, educators are anticipated to establish communicative and engaging experiences in a speaking class by providing learners with time, resources, and encouragement to learn the target language. Speaking has recently become a special field of language instruction. The opportunity to speak to non-native speakers, where English is learned as a second language, has always been a huge difficulty for learners, learners do not practice enough listening to develop the correct manner of communicating, restricted practice listening to poor speech skills. The deficiency of confidence with the failure to choose up the tone and pitch puts a huge impediment on the non-native learners. Low confidence whilst exploiting the English language is one of the major issues confronted by both educators and learners.

In accordance with this, recent reports have emphasized the use of technologies, such as computeraided language learning tools, to promote language learning (Heriyanto, 2018). The researcher has also recorded technology as an important method for improving student learning. A dynamic learning climate allows educators to use strategies that yield successful learning results. This rivalry accelerates further in the teaching of English as a Second Language (ESL) learners, considering their growing amount of 
1.5 billion (Beare, 2019). In the learning hemisphere, the use of emerging technology, such as videos and pictures, depends on the accomplishment of the multiple goals implemented internationally (Benmouhoub, 2015). Adding to it, technology plays a crucial role in teaching and studying languages. In reality, technology provides learners a wide variety of online learning materials and websites, as well as search engines and indexes, which are amazing sources of knowledge. Technology motivates Learners to learn to keep them involved for a long time to come. In addition, a number of reports show that a large number of innovations and multimedia materials may be incorporated into conventional ESL classrooms.

One of the most engrossing web channels that are widely being used in the education system nowadays is YouTube. Researchers around the globe have stated that YouTube is a valuable tool for improving learners' skills through the understanding of visual cues, especially in English (Kabooha and Elyas, 2018). The usage of YouTube in classrooms is becoming more popular as more and more educational videos are accessible online as a means of self-learning (Albahiri \& Li, 2018). Kabooha and Elyas (2018) demonstrated the increased propensity of scholars to investigate their usefulness in language learning in classrooms. The success of YouTube among users is also obvious from its increasing number of users, more than 1.8 billion per month in 2018 (Gilbert, 2018). There is an increased preference for the use of YouTube videos among ESL educators, aimed at leveraging English learning in ESL classrooms and complementing them with quality and diverse content.

Despite the massive revolution which has come about in the education sector, getting learners involved actively in the speaking lessons are still a stumbling block in executing a productive class. The learners still seem to lack speaking skills and confidence among learners in using the target language (English). The traditional learning atmosphere is not the current age learners' cup of tea, since they are Gen $\mathrm{Z}$ learners who are tech advanced who want to take responsibility for their learning process. The usage of conventional teaching methods often leads to why learners feel bored and have a poor performance in communicating (Mustapha, Abd Rahman \& Yunus, 2010). It, therefore, keeps them from being attentive or from participating actively in the language classroom. It has also been supported by Hashim (2018) that from millennial to Gen-Z, those would be the waves that come into the modern classroom and share distinctive characteristics that characterize their generations. These ages expect to be active in their learning and do not do well to be passive recipients of knowledge.

To overcome this problem, language educators ought to use an effective form of teaching and learning English, which can enable learners to use language with an emphasis on communicative purposes in real-life environments, rather than relying exclusively on precision as with conventional teaching. The introduction of information and communication technology (ICT) into the curriculum of pupils is certainly a superior teaching approach relative to traditional chalk and talk approaches, as learners have been able to concentrate more on the enjoyable and stimulating experience of learning (Yunus, Hashim, Embi \& Lubis, 2010; Hashim, Rafiq \& Yunus, 2019). In other terms, learners should be expected to express messages rather than to be worried about grammatical laws by using English for communicative purposes. With this, "MyScene Tube" has been innovated with the integration of short clips from several movies and the existing media platform which is called YouTube. "MyScene Tube" is a web channel that acts as a platform for learners to participate actively and confidently in speaking activities. This is because "MyScene Tube" focuses on enhancing learners' confidence and interest to utilize the target language which is English. This innovation will not only ease problems faced by many educators out there but also prepare the learners to be optimistic speakers who can face the challenging outer world. Therefore, this paper aims to investigate learners' confidence in utilizing the English language through the implementation of the "MyScene Tube" web channel.

\section{Literature Review}




\subsection{1st Century}

In this new century, the academic style of the learners is different from that of the previous generation, since they become more practical and emotionally involved in the learning process as stated by Kozinski (2017). The 21st-century learners are actively interested in their learning phase. They embrace obstacles and appreciate a highly immersive learning and community conversation environment. It is increasingly necessary for educators to prepare lessons that could be adapted to the needs of the new generation of learners to keep them interested in the lesson together with Industrial Revolution 4.0. As a consequence, many educators are overwhelmed by the variety of open language classroom methodologies and techniques. Throughout their search for the best solution, they should closely examine the potential of learners to better understand the skills needed to acquire knowledge. With the purpose to do that, the roles of educators will need to evolve so that they can fulfill the expectations of today's learners.

In addition to the traditional role of educator as an instructor, a variety of more suitable roles, such as associate or facilitator, are sought which are more important to this present century era, with the goal of improving the transformation of the program. Consequently, educators have begun to look at the goals, characteristics and outcomes of technology-based learning that can improve learners' speaking ability. The requirements for the skills of the twenty-first century appear to encourage technology-based learning without explicitly mentioning this. This is what makes the present amount so timely as to bridge these modern curriculum expectations with supporting pedagogy and technologies (Chu, Reynolds, Tavares, Notari \& Lee, 2017).

\subsection{Technology in Education}

It is no secret that in today's market environment, the growth of our culture needs emerging technology, particularly new knowledge and communication technologies stated by Abdurahimovna (2020). The widespread usage of computer software in education during the past decade has contributed to increased participation in teaching and learning methods. Technology motivates learners to learn and holds them involved for a long period. Many researchers have found that learners will learn more by seeing genuine and real-life clips (Hamad, Metwally \& Alfaruque, 2019). In conjunction with the Industrial Revolution 4.0, innovations are commonly utilized in the area of schooling. A variety of research has been performed on the usage of technology in teaching and studying languages. Anealka Aziz Hussin (2018) suggested that introducing technology to the classroom allows both educators and learners to build a successful learning atmosphere in order to strengthen teaching and learning processes. Anealka (2018) also indicated that instructors need to re-learn and empower themselves with interactive resources to suit the learning preferences of Gen $\mathrm{Z}$ learners.

The usage of technology has been an integral aspect of the learning experience in and out of the classroom. Typically, any language class utilizes some sort of technology that could help in enhancing language learning. Moreover, technology allows educators to adjust their instructional practices, thereby improving the process of language learning. Ahmadi and Reza (2018). The explanation behind showing interest in language learning is that we all realize that we live in a technical and competitive environment. If one wants to be efficient, one should have realistic skills. Today, learners are not involved in language learning. The explanation for these learners is so hooked to internet sites such as Google search, Wikipedia, Twitter, etc. (Abdurahimovna, 2020).

Haryanto and Kisman (2018) argued that educators should use videos as a web-based teaching mode and offered Learners the ability to use videos for self-learning. More recently, several scholars have sought to shed light on the crucial role of YouTube videos in teaching and learning in language classrooms. YouTube Videos, YouTube has become one of the most famous web channels in the world. 
It is known to be a hub of online content which plays a significant role in the teaching and learning of languages. It also provides learners with day-to-day language videos and authentic live scenarios that could assist them to develop their comprehension, efficiency and development of English. Hamad, Metwally \& Alfaruque (2019) emphasizes that YouTube is constantly being used by educators to teach English as it provides enjoyable and easy access to guidance, culture-based videos and languages from all over the world. In addition, Abdurahimovna (2020) discusses the usage of YouTube, Lifelong Vitality (LLVs) as a full language lesson that does not require additional language materials. It is argued that YouTube may be used to explore in the language classroom from simple to higher stages of education.

\subsection{Technology to Enhance Speaking Skills}

The capacity to speak is linked to the ability of learners to react and interact with others. Not only do you hear what the speaker wants to suggest, however, somebody has to be prepared to respond to it (Sari \& Margana, 2019). In speaking capacity, it can be claimed that an individual acts not only as a listener but also as a respondent or speaker. It can be interpreted that the way an instructor teaches if learners can develop their language skills, in particular speaking skills. It often extends to learning experiences both within and outside the school. Talking regarding activities is definitely linked to the imagination and honesty of an instructor. Educators should participate in a range of learning exercises, such as roleplaying, debate, sports, drill, or utilizing knowledge distance activities that can help learners practice communicating as they do in live conversation. In addition, the practice undoubtedly involves a learning media that encourages learning in order to enable learners to apply it outside or within the classroom.

According to Meinawati, Harmoko \& Rahmah (2020), with hundreds of millions of videos from contributors around the world, the online video platform allows it to be simpler than ever to learn English speaking. Nowadays, using YouTube as a multimedia platform is familiar to people, learners can easily learn how to communicate. The researcher also stated that by utilizing YouTube, learners get a chance to see how native speakers are communicating in the film. Learners may also practice mimicry, speech, intonation, and language, with satisfaction and faith in acting. In the meantime, this research centered on growing learner analytical thought by film, such that learners are able to talk fluently, learn grammar and vocabulary, and use English throughout their lives in both active and passive contexts. In comparison, the instructor may use a recording that is finished for the role play. It is more fun than seeing a movie as it is capable of improving the learner's speaking skills (Kolnel \& Zendrato, 2019).

\subsection{Advantages and Disadvantages of "YouTube" in Education}

In the last 25 years, the new school paradigm has taken many strides further in the evolution of the learning climate. As has been mentioned by Azlan, Zakaria, \& Yunus (2019), in the modern world of the Industrial Revolution 4.0, education is now inculcating emerging technology and creating a range of new ways of teaching and learning mediums, providing information and also encouraging alternative approaches to evaluation. Some of the gains we have found in this environment are attributable to the adoption of modern technological solutions for learners. Instead of providing a single machine for a class to use in contemporary days, technical advances have greatly affected the school system. New science has rendered it better and faster in the areas of health, engineering and construction.

Besides that, technology or the Internet, to be exact, gives thousands of learners all around the world the ability to read, communicate, exchange and analyze a specific lesson that will enable them to appreciate and ultimately incorporate the information they have gained in real life (Rajulain, 2020). In addition, technology convergence will promote active learning for learners (Orús, 2016). Astrimardila and Erwin (2017) also revealed that there is a possible achievement in the usage of technology that has 
influenced both learners and educators. Learners have been eagerly engaging in sharpening their English learning achievements; listening and talking to technology interactions, receiving a range of directions and an interesting learning environment. The instructor established his willingness to utilize interactive media methods (such as YouTube) to perform innovative teaching in classroom environments. One fragment of common technologies that can be effective in teaching and learning processes today is YouTube.

Moreover, Louafi Amina (2017) explored the efficacy of incorporating the E-learning tool in oral speech classes in improving learners' oral skills and noticed that the introduction of YouTube in EFL classrooms has a beneficial impact on learners' oral skills, enhances their engagement and involvement when learning in an immersive atmosphere and introduces them to authentic spoken language skills. Additionally, the usage of videos as teaching tools has a beneficial impact on learning enthusiasm (Nacak, Bağlama \& Demir, 2020). The researchers claimed that videos offer an incentive for actual things to be realized, shifting sequences to be seen and subjects to be heard. There are several benefits of utilizing YouTube videos in school. For example, it improves the persistence of learning and decreases the gaps between learners. Not only that, but it can also be used for several years on the basis of its repeatability, it is economic, it saves time and can be used in micro-education and quickly spread (Christ, Arya \& Chiu, 2017).

In contrast, technology, like every other thing, has pitfalls too. There are common claims that certain new developments make learners lazy and lead to obesity and other problems. Smart devices, laptops and other modern wonders are also being utilized in schools. There is no question that they are helpful, but in certain situations, they can have detrimental effects. McEwan, Belfield, Bowden and Shand (2017) found that the first downside of the Internet and its aided language learning services is that they would raise the expense of schooling and damage the equity of schooling. As technology becomes a new universal prerequisite for learners to buy, low-budget schools and low-income Learners are typically unable to afford a device. It would establish unequal educational standards for some disadvantaged schools and Learners. On the contrary, costly hardware and applications have become a huge responsibility for schools and parents. In fact, technology-aided language learning systems are also defective. Present computing technology is specifically associated with comprehension, listening and writing capabilities. While several speech programs have been created lately, their roles are still minimal. Kern, Ware \& Warsaw (2016) identified that the software should preferably be able to interpret the user's "spoken" feedback and test it not just for consistency but also for "appropriateness."

Apart from this, when learners surf on YouTube, "the website offers similar video suggestions and front-page highlights" (Gómez, 2020). Understanding how these features push video will help parents to stop watching harmful videos for children. It is simpler to draw potential customers by offering free content (Martínez, 2017). The right to use, distribute and create free content will offer a feeling of independence and power. On the opposite, this regulation may contribute to a profound reliance on emerging innovations, where young people lose sight of the truth in simulated environments run by big media providers and corporations. Social networking sites ought to be treated as complex objects that are tailored to suit the demands of their customers and their stakeholders.

\subsection{MyScene Tube}

YouTube is known to be one of the most successful ways to gain progress in English-speaking classes (Jalaluddin \& Mohammad, 2016). In accordance with this "MyScene Tube" is an innovation, which is a web channel innovated using movie scenes and YouTube. In other words, "MyScene Tube" is a kind of tool that can be really helpful for studying the language, both within and outside the school. The web channel enables users to access, display, rate, post and comment on videos. It helps unregistered users 
to access videos and registered users to post videos to their channels. It could be utilized in ESL classrooms to enhance learners' confidence and participation in speaking activities.

As stated by Yunus (2018), teachers encourage learners by providing them access to a vast variety of web-based resources that enable them to share their data and reach live audiences in real-world contexts. In conjunction with that, the reason why "MyScene Tube" is regarded as innovative is predominant because it encourages a more independent and student-centered learning model which is the preference of Gen $\mathrm{Z}$ learners. Moreover, it is not only a place of information but inspires learners as well. "MyScene Tube" offers learners an ability to present what they have experienced by voicing over a video based on their creativity and discussing it with their peers. Therefore, this research emphasizes on using "MyScene Tube" as a systematic tool for the learning of speaking skills, encouraging them to participate as well as boosting their confidence to utilize the target language, English.

To conclude, all of the over-recorded past considers fortifying the utilization of technology-based learning to create learners' speaking ability in line with 21st-century learning. Therefore, "MyScene Tube" could definitely benefit learners in various ways. Nonetheless, there could be a need to strongly inquire about how "MyScene Tube" helps to enhance learners' in other areas of language skills. As a consequence, the current research was expected to review the utilization of "MyScene Tube" to progress learners' basic speaking skills.

\section{Method}

\subsection{Research Design}

This research is mixed-method research. It is mixed-method research to investigate the use of "MyScene Tube" in enhancing learners' confidence and English-speaking skills.

\subsection{Research Participants}

The learners were at the age of 17-18 years with mixed genders and mixed abilities learners.

\subsection{Research Instruments/Tools}

There were two instruments used in this study for data collection which were questionnaires and YouTube analysis. The questionnaire consisted of three parts with a total number of twenty questions. The questionnaire was used to identify learners' opinions towards the implementation of "MyScene Tube" and how it has enhanced their speaking skills. The YouTube Analysis was analyzed using descriptive analysis. The analysis was made to identify the learners' confidence and the level of participation in the speaking activity.

\subsection{Research Procedure}

To accomplish the purpose of the present study, the following steps were executed during the research process. Firstly, a private secondary school was selected to use "MyScene Tube" over a period of 7 weeks in the speaking activity. At this instant, the educator explained the process of the project to the learners. Next, short clips of several movies were downloaded from YouTube and given to the learners. A total of 7 movie clips were selected from different genres and languages. The learners watched the clips and understood the flow of the story. Learners created their own dialogues for the clips based on their understanding and creativity. Learners edited and inserted their voices into the clips. Then, educators uploaded it on the YouTube channel. Finally, a set of questionnaires was distributed to the learners. The questionnaire was used to identify learners' opinions towards the implementation of "MyScene Tube" and how it has enhanced their speaking skills. Furthermore, The YouTube Analysis 
from 118 learners was analyzed using descriptive analysis. The analysis was made to identify the learners' confidence and the level of participation in the speaking activity. The results were collected from a questionnaire and YouTube Analysis.

\subsection{Data Collection Procedure}

First, all the learners were involved in a class speaking activity. The degree of involvement of the learners as well as their confidence in utilizing the target language was observed by the instructors. The learners employed "MyScene Tube" during their speaking lesson. The speaking activities with the implementation of "MyScene Tube" were carried out for a period of 7 weeks.

\subsection{Data Analysis Procedure}

Once the data collection period was over, the teacher analyzed the questionnaire and also the YouTube analysis using a descriptive analysis method. The percentages of scores obtained from the questionnaires were presented in a pie chart. Next, the data from the YouTube analysis were presented using line graphs. Finally, the outcome from both the instruments was discussed.

\section{Results}

This segment would discuss the data and findings contained in this report through a questionnaire and a YouTube analysis focused on the study objective. The results are laid out in two sections. The findings of the questionnaire will be seen in the first segment and the results of the YouTube review will be shown in the second.

\subsection{Questionnaire Results}

Table 1. Questionnaire Results

\begin{tabular}{|c|c|c|c|}
\hline \multirow[t]{2}{*}{ No. } & \multirow[t]{2}{*}{ Questions } & \multicolumn{2}{|c|}{ Students’ Response $\mathrm{n}(\%)$} \\
\hline & & Yes & No \\
\hline 1. & $\begin{array}{l}\text { Has "MyScene Tube" helped you to develop the confidence } \\
\text { to speak English? }\end{array}$ & $68.1 \%$ & $31.9 \%$ \\
\hline 2. & $\begin{array}{c}\text { Does "MyScene Tube" provide opportunities to speak } \\
\text { English? }\end{array}$ & $78.0 \%$ & $22.0 \%$ \\
\hline 3. & $\begin{array}{c}\text { Has "MyScene Tube" improved your English-Speaking } \\
\text { skills? }\end{array}$ & $65.9 \%$ & $34.1 \%$ \\
\hline 4. & Do you feel relaxed when practising "MyScene Tube"? & $67.4 \%$ & $32.6 \%$ \\
\hline 5. & $\begin{array}{l}\text { Has "MyScene Tube" helped you to practise English } \\
\text { speaking without the help of a teacher? }\end{array}$ & $75.8 \%$ & $24.2 \%$ \\
\hline 6. & $\begin{array}{c}\text { Would you recommend "MyScene Tube" to your other } \\
\text { friends? }\end{array}$ & $68.1 \%$ & $31.9 \%$ \\
\hline
\end{tabular}




\subsubsection{Confidence level in speaking English}

As shown in Table 1, the Question 1 result indicated that the percentage of learners who agreed that "MyScene Tube" has helped them in boosting their confidence to speak English is $68.1 \%$ which means more than half of the experiment group chose the option yes for the question. So, "MyScene Tube" has obviously helped the learners to develop their confidence in speaking English is significantly higher than to those who said that it does not help them to build their confidence level.

\subsubsection{Opportunity to speak in English with MyScene Tube}

Question 2 indicates the number of learners who accepted that "MyScene Tube" genuinely presented them with the opportunity to speak in English. The percentage of learners who agreed is 78\%, the result is substantially better than those who choose the "No" choice. Therefore, it can be inferred from the pie chart that "MyScene Tube" is a strong forum for learners to speak and practise English.

\subsubsection{MyScene Tube in Improving English-speaking skills}

Based on Question 3, the percentage in the table that illustrates learners' perception of "MyScene Tube" in brushing up their English-speaking skill is 65.9 percent. In contrast, the percentage which shows learners' opinion that this innovation did not improve their English-speaking skill is lower than from those who chose the option yes which is 34.1 percent. Thus, it can be clearly seen that "MyScene Tube" can help to ameliorate learners' English speaking skills.

\subsubsection{MyScene Tube in practising English speaking skills independently}

Question 4 in the table shows the outcome of learners who agreed that "MyScene Tube" allows them to practise speaking English independently without the guidance of their Educators. The percentage of learners who agreed is 75.8 percent, the outcome is significantly higher than those who chose the option "No" for the question. Therefore, it is strong evidence that supports "MyScene Tube" to be an effective platform for the learners to speak and practise English autonomously.

\subsubsection{Learners' anxiety level in utilizing MyScene Tube}

Question 5 in the table depicts the results of the learners' calmness when practising "MyScene Tube" in their English-speaking activity. 67.4 percent of learners' point of view indicates that they feel relaxed when they execute "MyScene Tube" in their speaking activity. However, 32.6 percent of learners said that their anxiety levels did not change when they implemented this innovation in their speaking activity. The difference in the percentage between learners who answered yes and no is 34.8 percent. Therefore, it can be concluded that utilizing "MyScene Tube" definitely helps in reducing learners' anxiety levels compared to conventional type of speaking activities.

\subsubsection{Recommendation of MyScene Tube}

Question 6 represents the percentage of learners who will recommend "MyScene Tube" to their peers in order to practise speaking in English. The percentage of learners who will recommend is $68.1 \%$ and it is notably higher than those who will not recommend. Hence, it can be seen that "MyScene Tube" remarkably benefitted the learners in enhancing their English-speaking skills. 


\subsection{YouTube Analysis}

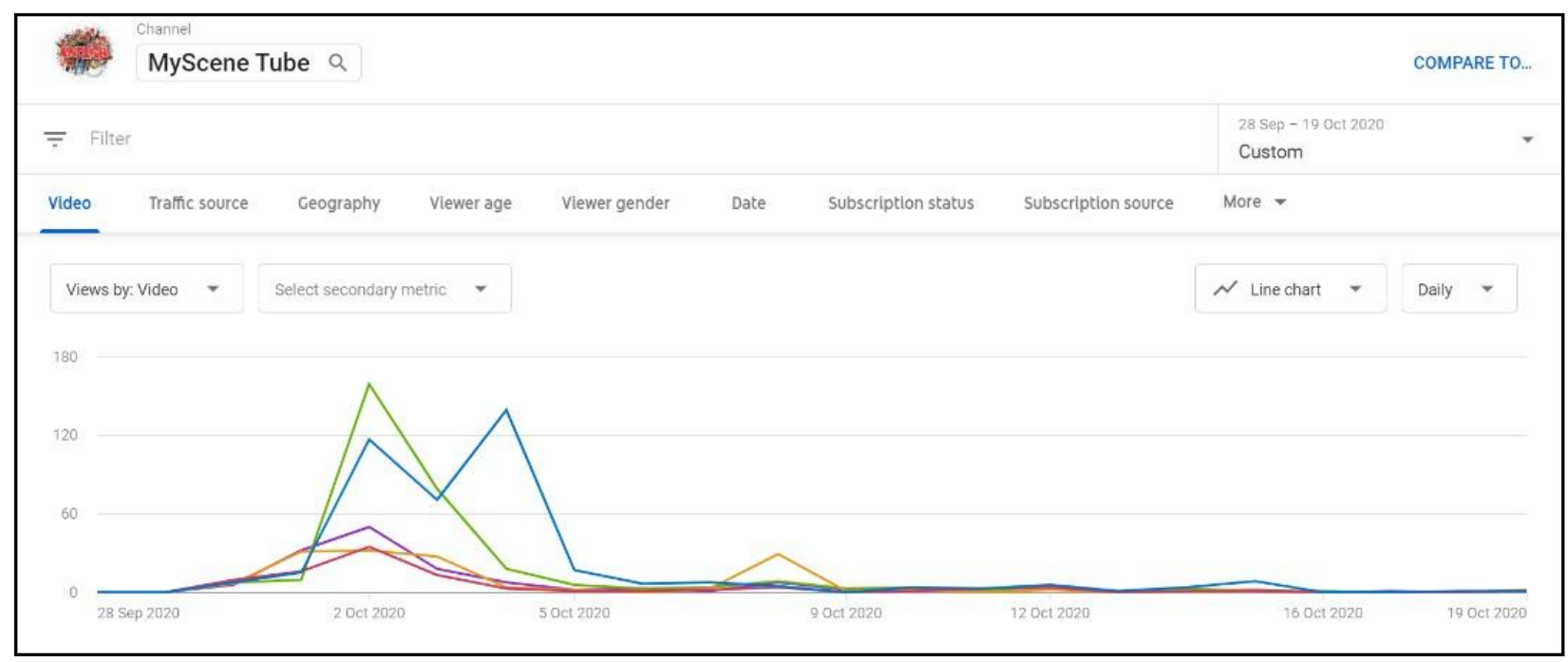

Figure 1. Number of viewers

Figure 1 shows the number of viewers for each video that has been uploaded on YouTube. The videos were uploaded on the YouTube channel on the 29th of September 2020. In the beginning stage, the number of viewers who viewed the videos uploaded was extremely low. However, as the days go by, the number of viewers for the videos uploaded surged drastically. The figure also shows that some of the videos have reached more than 100 viewers which depicts that the number of viewers soared significantly. This expansion has actually increased the confidence among the learners to perform better in their speaking activity using the target language as they are on the show on the social media platform.

Figure 2. Number of likes

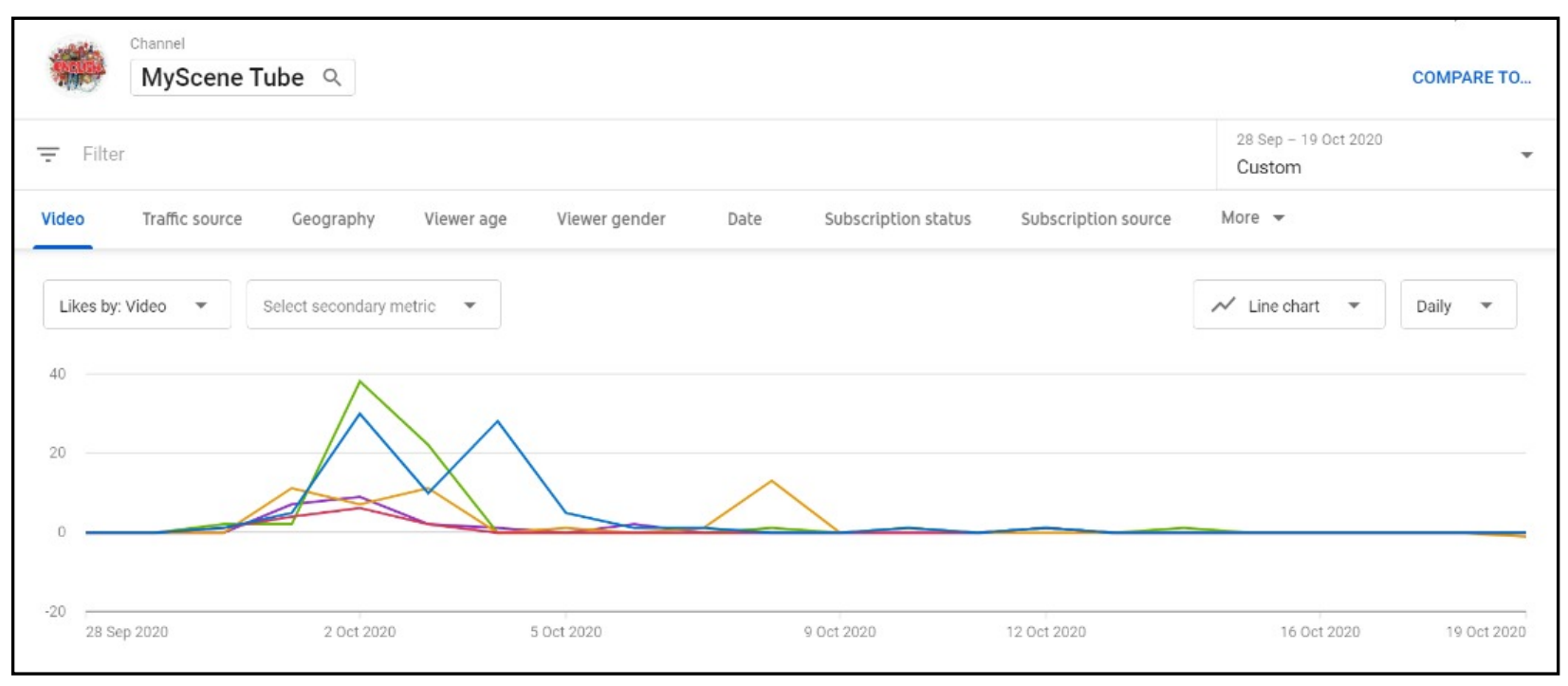

Figure 2 demonstrates the number of likes from viewers for each video that has been uploaded on YouTube. It also discloses that when the videos were uploaded, there were not many likes earned by the learners from the viewers, nevertheless, after a couple of days the number has started to plunge dramatically and some of the videos almost reached more than 100 likes around the date of 1st October 
2020 to 4th October 2020. This indicates that there is a sharp growth in the number of viewers who like the videos which they preferred. Consequently, this has indirectly augmented the learners' confidence in speaking using the target language - English.

\section{Discussion}

From the table, it can be seen that the learners are positive towards the implementation of "MyScene Tube". The outcome percentage shows a significantly higher number of learners who actually agreed that the implementation of "MyScene Tube" has enhanced their speaking skills. According to the results in Question 1 and 2, it shows that "MyScene Tube" has helped in boosting their confidence to speak in English as well as providing them with the opportunity to speak in English. Therefore, the use of "MyScene Tube" in English-speaking class settings is used as a pedagogical technique and as a mixture of theory and application. Next, the results from Question 3 supports that "MyScene Tube" is an effective tool that assists them in enhancing their speaking skills in the English language. In total, 65.9 percent of learners agreed that "MyScene Tube" has actually brushed up their English-speaking skills which cover almost two-thirds of the total experimental group number. Thus, it can be clearly seen that "MyScene Tube" could help to ameliorate learners' English speaking skills. It can also be seen that the implementation of "MyScene Tube" has contributed to intensifying the learners' speaking skills as well as their participation in speaking lessons, as supported by Prabhu, Vorne, Glaser, Rajagopalan, \& Beriwal (2017). The researchers also claimed that YouTube is indeed an interactive medium used by instructors to impart new skills and knowledge through videos.

Moving on to Question 4, the outcome illustrates that "MyScene Tube" necessitates the learners to speak English independently without the guidance of their educators. The number of learners who agreed that "MyScene Tube" produces autonomous speakers is $75.8 \%$, and the result is considerably better than those that have opted for the "No" alternative. There is also clear evidence that confirms "MyScene Tube" as a successful forum for learners to speak and practise English autonomously. In other words, the learners are participating actively and aiding one another without entailing their educator's guidance as "MyScene Tube" is a platform designed within Youtube, and Taslibeyaz (2018) stated that this resource to the provision of a network of active involvement of learners who succor each other in the course of achieving learning goals, and everyone has a commitment and benefit instead of passive learning. Adding on, "MyScene Tube" encourages learners to experience the thrilling learning process, not just through forceful imaginations in the study room, but with the aid of the newest technologies, allowing them to immerse themselves in a vivid, vibrant environment. Such a lesson creates a cognitive uplift in learners, and even learners with low academic results are able to collaborate with one another and enhance their speaking skills in the target language, English.

The results from Question 5 depict the results of the learners' anxiety level while utilizing "MyScene Tube" in their speaking lesson and a total of 67.4 percent of the learners' point of view shows that they felt relaxed while using "MyScene Tube". The results indicate that more than half of the experimental group learners stated that they felt relaxed while using "MyScene Tube" and it is strong evidence to support that using "MyScene Tube" would certainly help to minimize the level of discomfort in learners relative to traditional forms of speaking activities. From this, it can be seen that the learners prefer to use "MyScene Tube" in their speaking lessons compared to the traditional speaking activities as it allows them to work with minimal supervision and they are free to make decisions. This is supported by Abdurahimovna (2020) who stated that technologies do not substitute live contact with Educators and other means of knowledge, however, taking into account the desires of learners, they increase the interest in learning every discipline. The results from question 6 , are just a general finding to know to what extent the learners are interested in utilizing "MyScene Tube" in their speaking activities and recommending it to their peers for the benefits that they have gained from "MyScene Tube". Based on 
the table, the percentage of learners who will recommend "MyScene Tube" to their peers is $68.1 \%$ and it is notably higher than those who will not recommend it. As a result, it can be seen that "MyScene Tube" has amazingly enriched the learners by improving their English-speaking abilities, therefore, they have a strong desire to advocate for the benefits of everyone. Whitton \& Maclure (2017) supported that the use of videos in the learning process helps learners to create and interpret meaningful learning outcomes. In conjunction with this, "MyScene Tube" which implies the use of videos actually creates a fruitful outcome in learners' English speaking skill.

On the other hand, the analysis from the YouTube for "MyScene Tube" Channel delineates that the number of viewers and likes has contributed to the increase in learners' confidence to speak in English. The first line graph in Figure 1 shows that the number of viewers was extremely low in the beginning stage, but it has escalated after some time. This results in learners gaining their confidence level and sharing out their videos with their family and friends to be viewed. As what Papernot \& McDaniel (2018) has mentioned, there are many outer factors that can actually affect the learners' confidence level in the process of learning. As such, in this research, the number of viewers plays a major role in uplifting learners' confidence level in utilizing the target language. Adding on, in Figure 2, the line graph also reveals that when the videos were uploaded, there were not many likes obtained by the learners from the viewers. Having said that, after a few days, the number has started to surge greatly from the date of 1st October 2020 to 4th October 2020. This stipulates that there is an upward trend in the number of viewers who like the videos which they favor. Inevitably, it is proven that through "MyScene Tube", learners have boosted up their confidence and at the same time "MyScene Tube" has motivated the learners in speaking using the target language - English in comparison with the use of conventional method speaking lessons and this has been supported by Suryana, Hidantikarnillah, \& Oktavianti (2020).

In short, it can be concluded that "MyScene Tube" has enhanced the learners' speaking skills and also their confidence level in utilizing the target language, English. Educators should contemplate amalgamating the use of "My Scene Tube" in their speaking lessons as a higher number of learners enjoyed the implementation of this innovation because it has improved their speaking skills and confidence level in employing the English language.

\section{Recommendation}

Present research tends to focus on the enhancement of speaking skills among the learners with the implication of "MyScene Tube". It is not only beneficial to improve speaking abilities but also to teach reading, listening and writing skills. It is recommended that the "MyScene Tube" can be used by future researchers to explore the effectiveness of this innovation in enhancing learners' ability in different skills of the English Language. It is pertinent that research sheds light on learners' thoughts, opinions, views, and feelings on the implementation of "MyScene Tube". As the quote goes, "All the good speakers were bad speakers at first" by Ralph Waldo Emerson, "MyScene Tube" is a good platform that can instill confidence in learners and this will also encourage them to break their obstacles in expressing their view not only in the classroom but also in the outer world.

\section{Conclusion}

To conclude, it is important to note that today's learners are 21st-century learners, and they cannot be taught the same way as they were taught yesterday. Learners deserve to be aware of the learning cycle. "MyScene Tube" can be an extraordinary strategy for educating learners. Agreeing to the literature review which is based on diverse ponders, books and online articles, "MyScene Tube" could be an exceptionally compelling strategy to be implemented in speaking class as learners can show their own creativity invoicing over the movie scenes and share their thoughts with their peers. It still has 
many benefits and drawbacks. Instructors should be mindful of the pros and cons of utilizing "MyScene Tube" links. Educators should be issued special guidance for learners to use "MyScene Tube" in acceptable ways. Nobody may dispute the value of utilizing online tools to teach and practice English. It may be used in a number of forms for successful teaching and learning English. A teacher can use it in his or her own way that he or she feels would be productive and beneficial to learners.

\section{References}

Abdurahimovna, U. F. (2020). Advantages of using electronic learning resources in the educational process. European Journal of Research and Reflection in Educational Sciences, 8(8). https://www.idpublications.org/

Ahmadi, D., \& Reza, M. (2018). The use of technology in English language learning: A literature review. International Journal of Research in English Education, 3(2), 115-125. http://ijreeonline.com/files/site1/user_files_68bcd6/mohammadrezaahmadi-A-10-25-44989b1d.pdf

Al Kandari, A. M., \& Al Qattan, M. M. (2020). E-Task-based learning approach to enhancing 21stcentury learning outcomes. International Journal of Instruction, 13(1). https://doi.org/10.29333/iji.2020.13136a

Azlan, N. A. B., Zakaria, S. B., \& Yunus, M. M. (2019). Integrative task-based learning: Developing speaking skills and increase motivation via Instagram. International Journal of Academic Research in Business and Social Sciences, 9(1), 620-636. http://dx.doi.org/10.6007/IJARBSS/v9-i1/5463

Chiu, C. Y., Fu, H. W., Hou, H. S., Fan, Y. C., \& Huang, P. S. (2016). Influences of watching YouTube on Taiwanese English-major college Learners. 國立虎尾科技大學學報，33(3)，111-122. http://libwri.nhu.edu.tw:8081/Ejournal/AA01330307.pdf

Christ, T., Arya, P., \& Chiu, M. M. (2017). Video use in teacher education: An international survey of practices. Teaching and Teacher Education, 63, 22-35. https://doi.org/10.1016/j.tate.2016.12.005

Dharani, P. (2020). Traditional versus modern education system: A Deep Dive. International Scopus Journal of Scientific Research, 26(6), 206-219. https://arxiv.org/pdf/2008.04323

Dumlao, R. (2020). Beliefs, benefits, and challenges of using educational technology in language teaching: A voices from the secondary educators in Thailand. วารสาร ศึกษา ศาสตร์ มหาวิทยาลัย สงขลา นครินทร์ วิทยาเขต $\quad 31(1), \quad$ ปัตตานี, $38-59 . \quad$ https://so02.tcithaijo.org/index.php/edupsu/article/download/193641/164280/

Gómez, A. M. (2020). Children as products of consume in the apparent homemade videos of children's entertainment on Youtube. Las redes sociales como herramienta de comunicación persuasiva, 921.

Gore, J., Ware, M., White, S. L., Collins, L. A., Bowen, L., \& Hansen, C. (2019). Building the capacity of educators for supporting 21st-century learning. https://research.acer.edu.au/cgi/viewcontent.cgi?article=1372\&context=research_conference

Hamad, M. M., Metwally, A. A., \& Alfaruque, S. Y. (2019). The impact of using YouTubes and audio tracks imitation YATI on improving speaking skills of EFL Learners. English Language Teaching, 12(6), 191-198.: https://doi.org/10.5539/elt.V12n6p191

Hashim, H. (2018). Application of technology in the digital era education. International Journal of Research in Counseling and Education, 2(1), 1-5. DOI: 10.24036/002za0002 
Hashim, H., Rafiq, R. M., \& Yunus, M.M. (2019). Improving ESL learners' grammar with gamified learning. Arab World English Journal (AWEJ) Special Issue on CALL, (5). https://dx.doi.org/10.24093/awej/call5.4

Hassan Baig, M., Ahmad, K., Roy, S., Mohammad Ashraf, J., Adil, M., Haris Siddiqui, M., ... \& Choi, I. (2016). Computer-aided drug design: success and limitations. Current pharmaceutical design, $22(5)$

572-581. https://www.academia.edu/download/55766694/Computer_Aided_Drug_Design_Success_and_Li mitations_1.pdf

Hayriye, K. A. Y. I. (2008). Developing an ESL curriculum based on needs and situation analyses: A case study. Journal of Language and Linguistic Studies, 4(1).

He, P. (2018). On reading comprehension teaching for English majors under relevance theory. English Language Teaching, 11(1), 46-51. http://doi.org/10.5539/elt.v11n1p46

Hussin, A. A. (2018). Education 4.0 made simple: Ideas for teaching. International Journal of Education and Literacy Studies, 6(3), 92-98. http://dx.doi.org/10.7575/aiac.ijels.v.6n.3p.92

Jalaluddin, Mohammad. (2016). Using YouTube to enhance speaking skills in the ESL classroom. English for Specific Purposes World, 17(50), 1-4. http://www.esp-world.info/

Kabooha, R., \& Elyas, T. (2018). The effects of YouTube in multimedia instruction for vocabulary learning: Perceptions of EFL learners and educators. English Language Teaching, 11(2), 72-81. http://www.ccsenet.org/journal/index.php/elt

Kara, N., \& Cagiltay, K. (2017). In-service preschool educators' thoughts about technology and technology use in early educational settings. Contemporary Educational Technology, 8(2), 119-141. https://doi.org/10.30935/cedtech/6191

Kern, R., Ware, P., \& Warschauer, M. (2016). Computer-mediated communication and language learning. In The Routledge Handbook of English Language Teaching, 560-573. Routledge. http://www.warse.org/IJATCSE/static/pdf/file/ijatcse92922020.pdf

Kessler, G., \& Hubbard, P. (2017). Language teacher education and technology. The handbook of technology and second language teaching and learning, 278-292. DOI:10.1002/9781118914069

Kolnel, O. M. H., \& Zendrato, J. (2019). Implementation of the role-playing method to improve grade 1 Learners' speaking skills in an Indonesian Language lesson at primary school XYZ Gunungsitoli, Nias. Polyglot: Jurnal Ilmiah, 15(2), 333-347. http://dx.doi.org/10.19166/pji.v15i2.1058

Kozinsky, S. (2017). How generation $\mathrm{Z}$ is shaping the change in education. Retrieved 2nd August. https://www.forbes.com/sites/sievakozinsky/2017/07/24/how-generation-z-isshaping-the-changein-education/\#304059746520

Levin, H. M., McEwan, P. J., Belfield, C., Bowden, A. B., \& Shand, R. (2017). Economic evaluation in education: Cost-effectiveness and benefit-cost analysis. SAGE publications.

Lukas, B. A., \& Yunus, M. M. (2021). ESL Teachers' Challenges in Implementing E-learning during COVID-19. International Journal of Learning, Teaching and Educational Research, 20(2). https://doi.org/10.26803/ijlter.20.2.18

Martínez, C. (2017). Targeting children online. Young internet users and producers in the commercial media environment. (Doctoral dissertation). Swedish Research Council: Crafoord Foundation. https://lup.lub.lu.se/record/ce9cfdd0-1176-4db9-bb7b-af3b978817b7 
Meinawati, E., Harmoko, D. D., \& Rahmah, N. A. (2020). Increasing English speaking skills using YouTube. Polyglot: Jurnal Ilmiah, 16(1), 1-13. http://dx.doi.org/10.19166/pji.v16i1.1954

Mustapha, S. M., Abd Rahman, N. S. N., \& Yunus, M. M. (2010). Factors influencing classroom participation: a case study of Malaysian undergraduate students. Procedia-Social and Behavioral Sciences, 9, 1079-1084.

Nacak, A., Bağlama, B., \& Demir, B. (2020). Teacher Candidate Views on the Use of YouTube for Educational Purposes. Online Journal of Communication and Media Technologies, 10(2), e202003. https://doi.org/10.29333/ojcmt/7827

Orús, C., Barlés, M. J., Belanche, D., Casaló, L., Fraj, E., \& Gurrea, R. (2016). The effects of learnergenerated videos for YouTube on learning outcomes and satisfaction. Computers \& Education, 95, 254-269. https://doi.org/10.1016/j.compedu.2016.01.007

Papernot, N., \& McDaniel, P. (2018). Deep k-nearest neighbors: Towards confident, interpretable and robust deep learning. arXiv preprint arXiv:1803.04765.

Pazilah, F. N. P., Hashim, H., \& Yunus, M. M. (2019). Using Technology in ESL Classroom: Highlights and Challenges. Creative Education, 10(12), 3205. https://doi.org/10.4236/ce.2019.1012244

Precintha Rubini, A., James, P. P., Yong, K. L., \& Yunus, M. M. (2019). Hear me out! Digital storytelling to enhance speaking skills. Int. J. Acad. Res. Bus. Soc. Sci, 9, 190-202. http://dx.doi.org/10.6007/IJARBSS/v9-i2/5533

Rahman, A., Atmowardoyo, H., \& Salija, K. (2018). Podcast effects on EFL learners' listening comprehension. ELT WORLDWIDE, 5(2), 151-164. https://doi.org/10.26858/eltww.v5i2.7374

Rajulain, M. (2020). Learners self-created YouTube videos: A $21^{\text {st }}$-century speaking assessment. Diksi, 28(1). https://doi.org/10.21831/diksi.v28i1.28290

Sari, Y. N., \& Margana, M. (2019). YouTube as a learning media to improve the student's speaking ability in 21st century. Journal of English Language Teaching and Linguistics, 4(2), 263. DOI: 10.21462/jeltl.v4i2.296

Shahid, S. H., \& Ali, Z. (2017). Effects of video-podcast on listening comprehension of Saudi EFL learners. Europian Journal of English language Teaching, 2(4). http://dx.doi.org/10.46827/ejel.v0i0.1033

Shahid, S. H., \& Ali, Z. (2017). Finding the best length of video-podcasts: Effects of varied numbers of video-podcasts used on listening comprehension of Saudi undergraduates. International Journal of Novel Research in Education and Learning, 4(5), 19-31, Month: September - October 2017, Available at: www.noveltyjournals.com

Suryana, I., Hidantikarnillah, V., \& Oktavianti, I. N. (2020). Enhancing learners' English speaking skills through web-based teaching. EDUVELOP, 3(2),90-104. https://doi.org/10.31605/eduvelop.v3i2.601

Tryanti, R. A., Nonny, B., \& Moh, R. W. (2018). The impact of podcasts on EFL learners' listening comprehension. International Journal of English Linguistics, 8(6). https://doi.org/10.5539/ijel.v8n6p122

Waluyo, H. J., Suudi, A., \& Wardani, N. E. (2018). Suggestopedia-based storytelling teaching model for primary students in Salatiga. Malaysian Online Journal of Educational Technology, 6(1), 64-75. DOI: $10.17220 /$ mojet 
Yen, E. L. Y., \& Mohamad, M. (2020). Utilizing E-Learning to Assist Primary School ESL Pupils in Learning to Spell during COVID-19 Pandemic: A Literature Review. Creative Education, 11(8), 1223-1230. https://doi.org/10.4236/ce.2020.118091

Yunus, A., Callista, C., \& Hua, T. K. (2021). Exploring a Gamified Learning Tool in the ESL Classroom: The Case of Quizizz. Journal of Education and e-Learning Research, 8(1), 103-108. DOI: 10.20448/journal.509.2021.81.103.108

Yunus, M. M., Hashim, H., Embi, M. A., \& Lubis, M. A. (2010). The utilization of ICT in the teaching and learning of English: 'Tell Me More'. Procedia-Social and Behavioral Sciences, 9, 685-691.

Yunus, M. M. (2018). Innovation in education and language learning in 21st century. Journal of Sustainable Development Education and Research, 2(1), 33-34. https://doi.org/10.17509/jsder.v2i1.12355

Zeidler, D. L. (2016). STEM education: A deficit framework for the twenty-first century? A sociocultural socioscientific response. Cultural Studies of Science Education, 11(1), 11-26. https://doi.org/10.1007/s11422-014-9578-z

\section{AUTHOR BIODATA}

Chee Kooi Lian, Universiti Kebangsaan Malaysia, Faculty of Education, Postgraduate Student of Teaching English as a Second Language.

Devanageswari Kathiyaiah, Universiti Kebangsaan Malaysia, Faculty of Education, Postgraduate Student of Teaching English as a Second Language.

Farah Hani, Universiti Kebangsaan Malaysia, Faculty of Education, Postgraduate Student of Teaching English as a Second Language.

Vinotheni Chanderan, Universiti Kebangsaan Malaysia, Faculty of Education, Postgraduate Student of Teaching English as a Second Language.

Dr. Melor Md Yunus, Universiti Kebangsaan Malaysia, Faculty of Education, Field of Language Education and Innovation. 